\title{
PSYCHE.
}

\section{SKETCH OF THE HABITS OF NORTH AMERICAN ANTS-II.}

BY AUGUSTE FOREL, CHIGNY PRÉS MORGES, SWITZERLAND.

Translated by A. P. Morse.

Appendix to the preceding letter. (unpublished).

After sending this account to your Society I made a visit to Mr. Pergande and compared in part my gatherings with lis collection. The Eciton is E. arolinense Emery.

I forgot to say that the E. carolinense had only larvae and worker pupae in the nest. I could find the larvae of neither males nor females, which is much to be regretted.

The conclusion of my journey presented still other interesting facts, which follow:

Arrived at Washington, on the way from Faisons, I was received in most welcome fashion by my estimable colleague Mr. Pergande, entomologist of the Dept. of Agriculture of the U. S. Mr. Pergande aided me in finding numerous species of ants whose dwellings lue knew and his beautiful collection afforcled an opportunity to make instructive comparisons.

A small Formica found near Mr. Tyson's in a very small nest of woody materials, like a miniature of $F$. integra and its nest, is $F$, difficilis Emery. I took its curious yellow female also. It has exactly the appearance of intcrat and pratensis.

I discovered also the beginning of a formicary of Cimponotus marginatus Latr., that is to say the female alone with some cocoons.

Then Mr. Pergande showed me in the earth the nests of a black Monomorium different from ebeninum (carbonarium var.?; minutum according to Emery), with the metanotum rounded. I have found it since then frequently, nesting in the ground, while cbeninum seems to nest regularly in dead wood and hollow stems.

A nest of Formica obscurizentris Mayr was constructed like those of integra, but I saw no roads.

In hunting under logs along the Potomac we found Stenamma diecki, Strumigrenys clypeata, Proccratium crassicome, and other rarities of secluded habits. Even in the streets of Washington two formicaries of large Tetramorizm caespitosum L. waged deadly war against each other on the sidewalks, a habit of these ants as McCook and I have already described.

At Cromwell, Ct., where I stopped afterward, I found some colonies of Formica cxsectoides with more woody 
materials. I placed a handful of exsec toitles from a nest in a wood, about five hundred paces from another, toward the latter, in order to discover if they were of the same colony. Some workers seized the newcomers for an instant by the legs. Aside from this, peace and fusion. The experiment is not, however, conclusive, because in Europe we see $F$. exsecta of different colonies behave in nearly the same manner.

By making some $F$. cxscctoides fight with other species (pallidefulver and sanguinea), I was able to ascertain that they have not, like exsecta of Europe, the instinct to seize their enemies by the neck, in order to saw it apart. Their analogy with their European congener is, therefore, only partial.

At Cromwell, in the brush of a cleated woodlot, I had the good fortune to be present at the attack on a formicary of huge $F_{0}$ subsericea by a feeble band of $F$. sanguinca, smaller and much less numerous. The sanguinca were scarcely thirty in number and a third of them were recently enclosed workers, still immature.

Evidently it was a newly started formicary which was thus engaged. The subserice had their nest at the foot of a large mullein (Verbascum). In number they were at least tenfold their aggressors. Each of them was, I can affirm, as well armed and on an average larger than and equally as robust as any of the assailants. Well, the mere arrival of this little troop of sangminca was suffcient to spread a panic in the formicary of subserice which fled with their larvae and pupae without attempting any serious defense, allowing the sanguinca to seize their young and take possession of their nest. Only one or two small sanguinca were killed. The instance is noteworthy because in this case neither the formidable weapons, the violence, nor the impetuosity of the little band of Polyergus rufescens whose similar aggressions I have described in my "Fourmis de la Suisse" can be alleged. The bold and courageous tactics of the sanguinea were even somewhat less marked than among those of Europe, which fight with species smaller and weaker than themselves. I have never seen a cowardice so absurd or so complete as that of these American subscricea, and this cowardice indicates very clearly the instinctive adaptation of the slave-making species to attack and of the enslaved species to flee.

At Hartford, Ct., I discovered a small mixed formicary of Formica cxsectoides and $F$. subsericed. There was scarcely any doubt of the common and intimate life of the two species in the same nest. They went in and out at the same doors, etc. Here the artificial experiments of a myrmecologist were excluded. This case is undoubtedly the same as that described for the first time in my "Fourmis de la Suisse," that is to say, an abnormal, mixed, natural formicary resulting from a battle between the two species, a battle in which exsctoides had the best of it and had raised the pupae taken from subsericca. Here, as in Switzerland, the mixed formicary was not populous, much less so than those of exsectoides 
usually are. The nest was small. I believe it necessary to be cautious and to ask if the apparent association of different species of Formica is not also due at times to the association of fertile females of the two species. The fact could, on occasion, be verified. At Hartford time did not permit me to do this.

In the suburbs of Isoston (Franklin Park) I found anong others a Strumigenys, some Brachymymex heeri, a CrCmastogaster, and a solitary worker of Polyergus lucidus, a fact which is astonishing if one considers that the latitude of Boston is nearly $45^{\circ} \mathrm{N}$. [more nearly $42^{\circ} 20^{\prime}$ ] (nearly the same as Turin), and that it is much colder than in the same latitude in Europe. Now these genera of ants love heat.

In the old world the number of species is less in continental than in maritime climates. Thus the ant-famma of Bulgaria is much scantier than that of the south of France. Besides, the fauna there is upon the whole less southern. But it is necessary to take into account other factors without which one cannot understand why the fauna of North America, in spite of the continental climate of the country, is so much richer than ours.

However, one finds, even with us, some exceptions. Thus Mymeroiystus riaticus, a southern form, extends far- ther north in eastern Europe (continental climate) than in western Europe (maritime climate). 'This species, therefore, stands a rigorous winter well provided it has a hot and dry summer, while with others it is for the most part the contrary. But it is evident that for America there are some facts of prehistoric geological geography which have contributed to preserve there a fauna and flora very much richer than in the Old World. This fact is well known and of great interest, considering the close relationship between the nearctic (North American) fauna and fora on the one side and the palearctic (northern Old World) fauna and flora on the other, a relationship which is antecedent to the glacial epoch, when the two fatunae were connected by Greenland. Noreover, one observes some facts in America analogous to those of the Old World. Thus North Carolina has in its western part a distinctly continental climate, while in the east the Gulf Stream gives it one of somewhat maritime character. Now, the ant-fauna of the state is much richer in the east than in the west. It is true that the western part is also somewhat more elevated; but the mild winter is without doubt the principal cause of this wealth. 

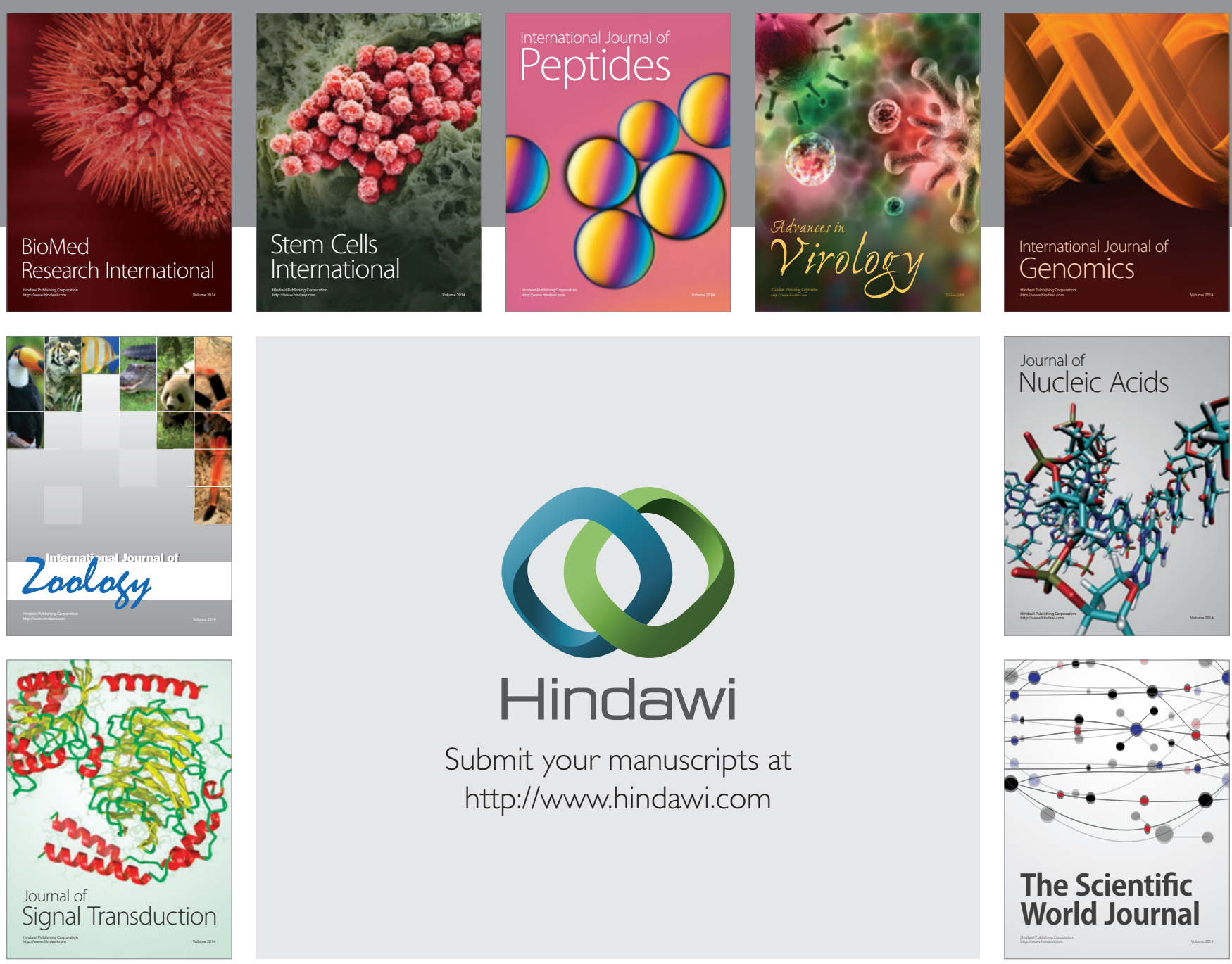

Submit your manuscripts at

http://www.hindawi.com
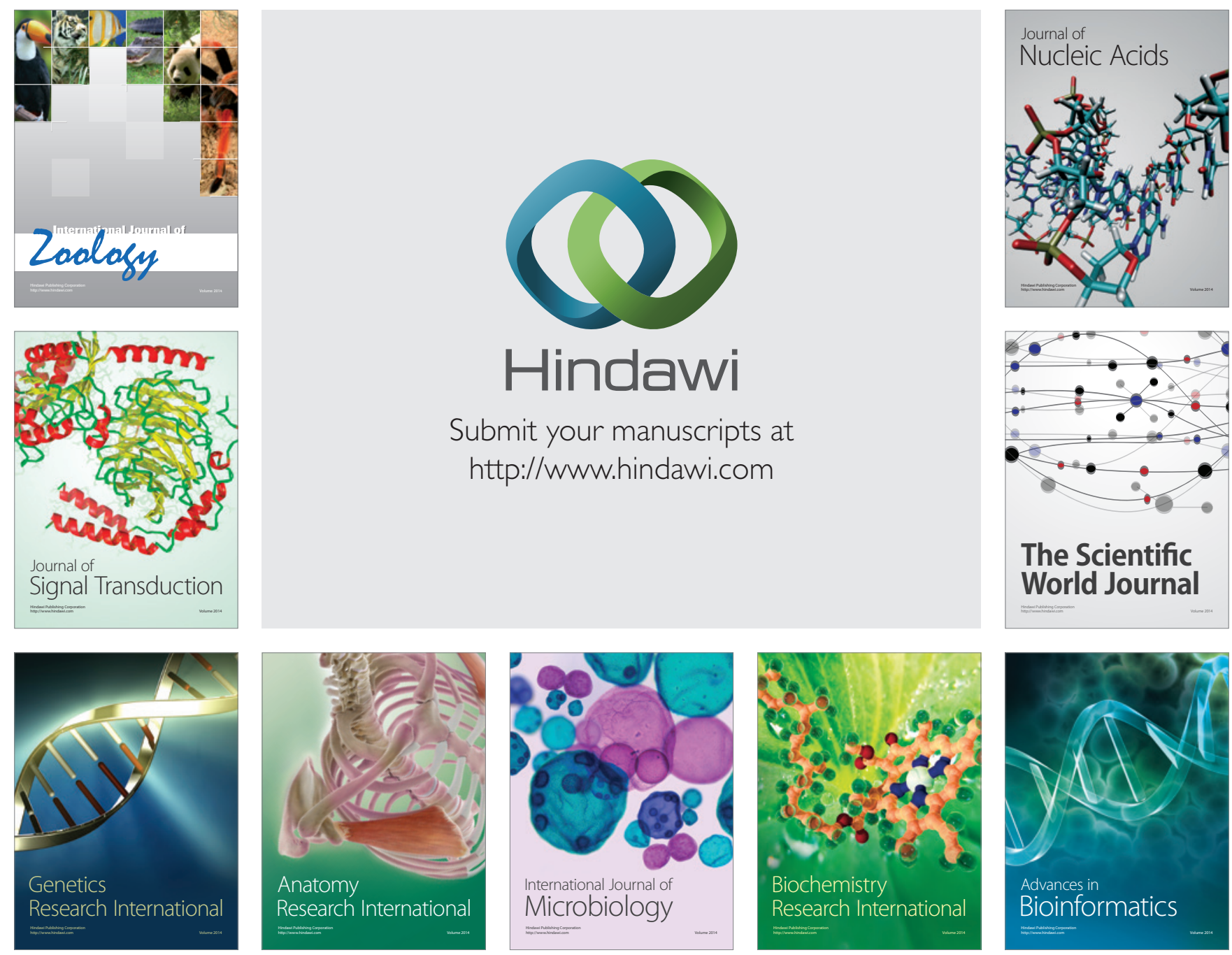

The Scientific World Journal
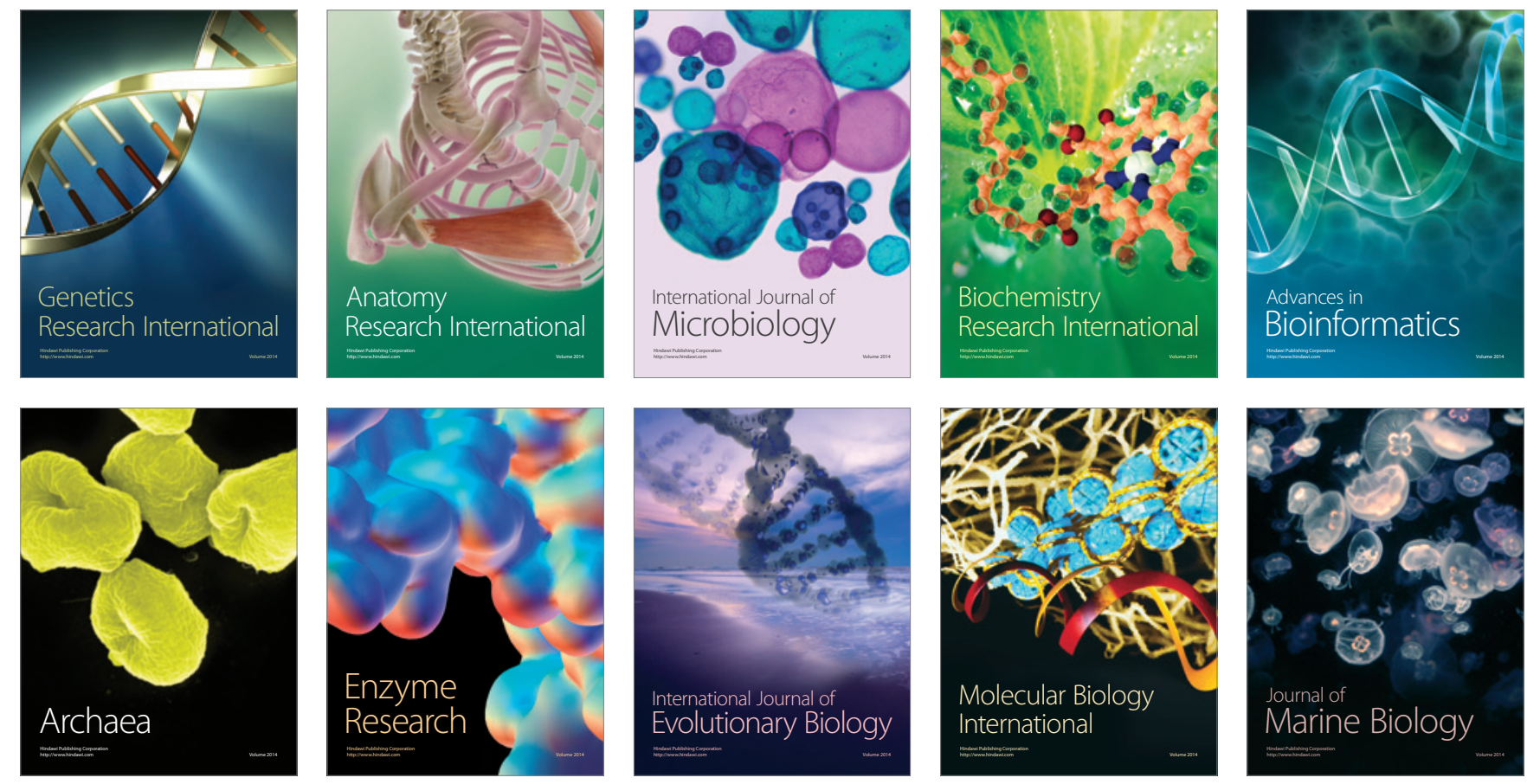